\title{
RESENHA
}

\section{O DISCURSO HISTÓRICO COMO REPRESENTAÇÃO DE UMA CIÊNCIA DO SUJEITO: A OPERAÇÃO HISTORIOGRÁFICA EM MICHEL DE CERTEAU}

\author{
Juliana da Silva Monteiro*
}

CERTEAU, Michel de. A Escrita da História. Tradução de Maria de Lourdes Menezes. Rio de Janeiro: Forense Universitária, 2010. 345p.

Michel de Certeau nasceu em 17 de maio de 1925 em Chambéry, interior da França. Foi um exímio historiador e intelectual jesuíta.Certeau teveuma formação bastante eclética, interessando-se por diversos temas como, psicanálise, misticismo, linguística, história religiosa, cultura e a vida cotidiana. Formou-se em Letras Clássicas, Filosofia, Teologia e História, com doutorado em Ciência das Religiões. Era membro da Escola Freudiana de Paris e lecionava na Universidade de Paris VII. Faleceu prematuramente em 1986, em consequência de um câncer de pâncreas.

Dotado de uma inquietude epistêmica, Certeau foi um grande questionador. Conhecido inicialmente como o historiador do misticismo, Certeau ganhou ainda mais notoriedade no campo da epistemologia da História e da produção do conhecimento historiográfico ao escrever uma importante obra intitulada A Escrita da Históriaem 1975, objeto da presente resenha.

A Escrita da História é reconhecidamente uma obra clássica e significativa do campo da História e da Historiografia, bem como para o ofício do historiador. Como sabemos, toda investigação que se preza possui um questionamento central, melhor dizendo, um problema de pesquisa, que provoca, incomoda e confronta o saber constituído. Neste livro, o que incomodava Certeau era justamente o desafio de responder uma pergunta um tanto instigante: Como se produz história? Ou melhor, como fazer história?

Para tanto, na primeira parte do livro, da qual iremos nos aproximar mais, Certeau (2010) explica que a historiografia faz surgir a interrogação sobre o real em duas posições diferentes do procedimento científico: o real enquanto é o conhecido e o real enquanto implicado pela operação científica. De um lado o real é o resultado da análise e, de outro, é o postulado. A ciência histórica existe, precisamente, nessa relação.

A preocupação de Certeau é apontar que a história não está ligada ao objeto em si, portanto, a história não é o real. A história é uma produção de discurso sobre o real, jamais será a própria realidade vivida. É por isso que, nesse livro Certeau nos ajuda a entender que o historiador jamais resgata a história ou um fato histórico, pois o que foi vivido não pode ser recuperado em sua essência, o que o historiador faz é uma construção historiográfica.

Nesse sentido, Certeau evidencia em sua obra que, a historiografia é muito mais uma

\footnotetext{
*Doutoranda em Educação pelo Programa de Pós-graduação em Educação da Universidade Federal da Grande Dourados -PGEDU/UFGD. Mestre em Educação (UFGD). E-mail: jumonteiro_psi@ hotmail.com.
} 
forma de construção e de fabricação específica do que uma ressurgência de uma realidade passada. Essa preocupação do historiador vai marcar fundamentalmente a ideia central do seu livro, ou seja, encarar a história como uma operação, compreendendo-a em torno de três combinações fundamentais. Nesta perspectiva, "a operação histórica se refere à combinação de um lugar social, de práticas científicas e de uma escrita" (CERTEAU, 2010, p.66).

Ao afirmar que toda pesquisa historiográfica se articula com um lugar social, Certeau quer dizer que o fazer historiográfico está implicado com um lugar de produção socioeconômico, político e cultural. É em função desse lugar que se instauram os métodos, que se delineiam temas e interesses, que se organizam os documentos e as questões que são propostas, o que é possível de ser dizível e o que permanece como não-dito.

Fazer história é uma prática científica, o que implica em técnicas de produção e procedimentos de pesquisa. Isso significa que em seu ofício, o historiador também seguirá as regras da ciência e da academia no próprio sentido pragmático, pois ele utilizará métodos e técnicas para produzir o conhecimento científico e legitimar o seu trabalho, ao realizar pesquisas em arquivos, aoselecionar, interrogar, entrecruzar e analisar as fontes, transformando-as em documentos e produzindo sentidos.

Em história, tudo começa com o gesto de separar, de reunir, de transformar em documentos certos objetos distribuídos de outra maneira. Esta nova distribuição cultural é o primeiro trabalho. $\mathrm{Na}$ realidade, ela consiste em produzir tais documentos, pelo simples fato de recopiar, transcrever ou fotografar estes objetos mudando ao mesmo tempo o seu lugar e o seu estatuto (CERTEAU, 2010, p.81).

O fazer historiográfico implica na construção de uma escritasobre o real. A escrita da história produz uma inversão escriturária, que conduz da prática ao texto. Para Certeau (2010), de fato, a escrita histórica permanece controlada pelas práticas das quais resulta, bem mais do que isto, ela própria é uma prática social que confere ao seu leitor um lugar bem determinado, redistribuindo o espaço das referências simbólicas e impondo, assim, uma lição.

Certeau (2010) vai dizer ainda que a escrita da história funciona como imagem invertida, um espelho da realidade, pois dá lugar a falta e a esconde, cria relatos do passado que são o equivalente dos cemitérios nas cidades, exorciza e reconhece uma presença da morte no meio dos vivos. Não é por menos que, curiosamente, Certeau vai dizer de maneira metafórica que a história é um trabalho de ressurreição dos mortos. "A escrita põe em cena uma população de mortos - personagens, mentalidades ou preços” (CERTEAU, 2010, p.106).

Certeau conclui e analisa brilhantemente, tomando emprestado o paradigma da psicanálise lacaniana, que o discurso histórico é a representação privilegiada de uma ciência do sujeito, desse sujeito tomado numa divisão constituinte, mas com a representação das relações que um corpo social mantém com a sua linguagem. Em outras palavras, tanto o discurso histórico quanto o sujeito são constituídos e determinados genuinamente pelo Outro da linguagem.

Não menos importante, na segunda parte do livro, Certeau aborda a produção do tempo e uma arqueologia religiosa, a partir de uma experiência da história religiosa moderna. $\mathrm{Na}$ terceira parte, ele discute sobre a escrita da história e a oralidade etnológica. Por fim, na quarta parte, Certeau dedica um espaço para as escritas freudianas e a Psicanálise, ao refletir o que Freud fez da história, ou melhor, Certeau busca um ponto de encontro entre essas duas ciências, ao perceber e demonstrar as similitudes dos procedimentos científicos que a Psicanálise e a História possuem em comum.

Revista Educação e Fronteiras On-Line, Dourados/MS, v.9, n.26, p.166-251, maio/ago. 2019 
A Escrita da Históriaselegitimacomo leitura obrigatória não somente para os historiadores, mas para todos aqueles que se dedicam às ciências humanas de um modo geral. $\mathrm{Na}$ verdade, é um livro que precisa ser lido e sempre revisitado, pois a cada releitura, novos questionamentos epistemológicos são despertados, condição sinequa nonpara o sujeito da ciência, que é por essência, sujeito da linguagem.

Enfim, não somente essa, mas outras obras do autor merecem leitura, entre elas: $A$ invenção do cotidiano 1: artes de fazer; $A$ invenção do cotidiano 2: morar, cozinhar e $A$ Cultura no plural.

Recebido em: 21/02/2019

Aprovado em: 26/04/2019 